\title{
Flipped Class room : An effective ICT tool for Facilitators and Remote location Learners
}

\author{
A Padmaja ${ }^{a}$, Swapna Srinivasan ${ }^{b}$, Sheetal Bhongle ${ }^{c}$ \\ ${ }^{a}$ Vidya Jyothi Institute Of Technology,Hyderabad-75,Telangana,JNTUH \\ ${ }^{b}$ Mangalore Institute of Technology and Engineering,Moodabidri \\ ${ }^{c}$.D.Y.Patil College of Engineering Akurdi,Pune \\ aprincipalvjit@vjit.ac.in \\ bswapna@mite.ac.in \\ csheetalatdbncoet@gmail.com
}

\begin{abstract}
The flipped classroom is a new type of teaching model produced under the modern information society. It subverts the traditional teaching mode. It is better to achieve students' independent cooperation to explore the learning model that greatly enhances the interaction between teachers and students. The reform of teaching methods in colleges and universities also has important significance. This requires understanding of effective teaching methods to manage the transition from the traditional to the flipped learning. Keeping in view the reforming teaching and learning approach, authors have designed a course on flipped class room and studied the engagement of participants on the gnomio cloud platform. This paper's main objectives are,
\end{abstract}

- To familiarize the facilitator with teachinglearning scenario with Flipped Classroom Model.

- To Design an out-class activity and in-class activity.

- To Design a Flipped-classroom activity with Blended Learning Strategy

Participation of individual learner ability on the course and transition pattern of engagement of learners in knowledge quiz, Reflection Quiz and assimilation quiz have been analyzed. Perception of the learners also has been analyzed. The paper would be highly beneficial to all the faculty members in designing their courses and in getting to know the learning capabilities of teachers.

Keywords: Flipped Class room, remote learners, in class activity and out class activity

Introduction: In traditional teaching learning process, only transmission of information takes place. In such a case the teacher gives lecture and the student act as a listener. Flipped classroom is a technique which creates a platform to the students in sharing their thoughts in this classroom and the teacher acts as a facilitator resulting in the student becoming an active learner. To overcome the limitations of traditional teaching leaning process, we use flipped classroom. Most common problem in traditional classroom is that the teacher is teaching but the students do not pay attention to the lecture. During question-answer session, the topper and a few more students involve but rest of the class remains silent. Here we are using ICT based techniques to change traditional classroom into flipped classroom. Also, by using flipped classroom technique we can identify the ability of students with respect to completion of different tasks. Flipped classroom is a leaner-centric teaching process. In this, some activities are conducted inside the class and some are conducted outside the classroom. The activities which are conducted outside the classroom are done with the help of ICT tools. In traditional classroom, teachers are not available to solve the problems of students after their lecture time but with the help of ICT tool we are able to design flipped classroom and teachers are available for students whenever they need help. As teachers, we can easily provide notes to students and they are free to discuss their doubts at any time. ICT based tools are done in WordPress, which means we can create a website and interact with students. Moodle is the best ICT tool for designing subject specific class. Google classroom also creates class for students and we can post different assignments and activities for students. Studies have shown that faculty \& students today are utilizing educational videos as a tool for learning everything from changing a tyre to the latest technologies. Abstract topics that once seemed difficult to teach and learn are now more accessible and understandable. Thanks to the availability of educational videos!

\section{Methodology}

The moodle course in WordPress is designed as part of the FDP Design Activity in IITBombayX: FDP301x Mentoring Educators in Educational Technology, in which, participants for the course were from the same FDP. The course involves the following activities that are to be 
completed by participants during the course:

LeDs: You have to watch 4 LeDs (Learning Dialogue) videos on

1. Flipped class room : What is flipped class room?/benefits in engaging through flipped class room

https://www.youtube.com/watch?v=QaNWTCgoO $\underline{\mathrm{zM}}$

2. How to design out class activity?

https://screencast-omatic.com/watch/cF1DQOFQEm

3. How to design in class activity ? https://www.youtube.com/watch?v=ig5DGG5DN $\underline{\mathrm{wU}}$

4. $\quad$ Linking up In-class \& Out-class activity

LbDs: You have to complete 7 LbDs(Learning by Doing)

1. Discussion on Flipped classroom (LxI)

2. Additional Learning Material/Resources (LXT)

3. Knowledge Quiz, Assimilation Quiz, Reflection Quiz

4. Feedback Forms : Complete the 3 Feedback forms.

\section{Flipped class room Course designed link}

https://team093.gnomio.com/course/view.php?id=2

\section{Corresponding Author}

aPrincipal,Vidya Jyothi Institute Of

Technology,Hyderabad-75, Telangana,JNTUH

${ }^{\mathrm{b} S e n i o r}$ Assistant Professor,Mangalore Institute of

Technology and Engineering,Mangalore

${ }^{\mathrm{c}}$ Asst.Prof.D.Y.Patil College of Engineering Akurdi,Pune emailcorresponding.author@ corresponding.com

\section{Results and Discussion}

\section{ANALYSIS OF ENGAGEMENT}

14 Participants have enrolled to the course

The activity completion report generated from the course reports section shows the engagement of participants in the activities as shown in Table 1

Table 1: Activity Completion Summary

\begin{tabular}{|l|c|c|}
\hline \multicolumn{1}{|c|}{ Activity } & Completion & Completion Status \\
\hline $\begin{array}{l}\text { Course Entry } \\
\text { Survey }\end{array}$ & 4 & 40 \\
\hline LeD 1 & 14 & 100 \\
\hline LeD 2 & 14 & 100 \\
\hline LeD 3 & 14 & 100 \\
\hline LeD 4 & 14 & 100 \\
\hline Discussion & 10 & 71.42 \\
\hline
\end{tabular}

\begin{tabular}{|l|l|l|}
\hline Knowledge Quiz & 09 & 64.28 \\
\hline Assimilation Quiz & 09 & 64.28 \\
\hline Reflection Quiz & 06 & 42.85 \\
\hline Feed back Survey & 05 & 35.71 \\
\hline
\end{tabular}

Table 2: Participation of individual learners in the course

\begin{tabular}{|c|c|c|c|c|c|c|c|}
\hline $\begin{array}{l}\text { Activi } \\
\text { ties }\end{array}$ & 1 & 2 & 3 & 4 & 5 & 6 & 7 \\
\hline $\begin{array}{l}\text { Cours } \\
\text { e } \\
\text { entry } \\
\text { surve } \\
\text { y }\end{array}$ & $\begin{array}{l}\text { Comp } \\
\text { leted }\end{array}$ & $\begin{array}{l}\text { Not } \\
\text { Comp } \\
\text { leted }\end{array}$ & $\begin{array}{l}\text { Not } \\
\text { Comp } \\
\text { leted }\end{array}$ & $\begin{array}{l}\text { Comp } \\
\text { leted }\end{array}$ & $\begin{array}{l}\text { Not } \\
\text { Comp } \\
\text { leted }\end{array}$ & $\begin{array}{l}\text { Comp } \\
\text { leted }\end{array}$ & $\begin{array}{l}\text { Not } \\
\text { Comp } \\
\text { leted }\end{array}$ \\
\hline LeD1 & $\begin{array}{l}\text { Comp } \\
\text { leted }\end{array}$ & $\begin{array}{l}\text { Comp } \\
\text { leted }\end{array}$ & $\begin{array}{l}\text { Comp } \\
\text { leted }\end{array}$ & $\begin{array}{l}\text { Comp } \\
\text { leted }\end{array}$ & $\begin{array}{l}\text { Comp } \\
\text { leted }\end{array}$ & $\begin{array}{l}\text { Comp } \\
\text { leted }\end{array}$ & $\begin{array}{l}\text { Comp } \\
\text { leted }\end{array}$ \\
\hline LeD2 & $\begin{array}{l}\text { Comp } \\
\text { leted }\end{array}$ & $\begin{array}{l}\text { Comp } \\
\text { leted }\end{array}$ & $\begin{array}{l}\text { Comp } \\
\text { leted }\end{array}$ & $\begin{array}{l}\text { compl } \\
\text { eted }\end{array}$ & $\begin{array}{l}\text { Comp } \\
\text { leted }\end{array}$ & $\begin{array}{l}\text { Comp } \\
\text { leted }\end{array}$ & $\begin{array}{l}\text { Comp } \\
\text { leted }\end{array}$ \\
\hline LeD3 & $\begin{array}{l}\text { Comp } \\
\text { leted }\end{array}$ & $\begin{array}{l}\text { Comp } \\
\text { leted }\end{array}$ & $\begin{array}{l}\text { Comp } \\
\text { leted }\end{array}$ & $\begin{array}{l}\text { compl } \\
\text { eted }\end{array}$ & $\begin{array}{l}\text { Comp } \\
\text { leted }\end{array}$ & $\begin{array}{l}\text { Comp } \\
\text { leted }\end{array}$ & $\begin{array}{l}\text { Comp } \\
\text { leted }\end{array}$ \\
\hline LeD4 & $\begin{array}{l}\text { Comp } \\
\text { leted }\end{array}$ & $\begin{array}{l}\text { Comp } \\
\text { leted }\end{array}$ & $\begin{array}{l}\text { Comp } \\
\text { leted }\end{array}$ & $\begin{array}{l}\text { compl } \\
\text { eted }\end{array}$ & $\begin{array}{l}\text { Comp } \\
\text { leted }\end{array}$ & $\begin{array}{l}\text { Comp } \\
\text { leted }\end{array}$ & $\begin{array}{l}\text { Comp } \\
\text { leted }\end{array}$ \\
\hline $\begin{array}{l}\text { Discu } \\
\text { ssion }\end{array}$ & $\begin{array}{l}\text { Comp } \\
\text { leted }\end{array}$ & $\begin{array}{l}\text { Comp } \\
\text { leted }\end{array}$ & $\begin{array}{l}\text { Not } \\
\text { Comp } \\
\text { leted }\end{array}$ & $\begin{array}{l}\text { Not } \\
\text { Comp } \\
\text { leted }\end{array}$ & $\begin{array}{l}\text { Comp } \\
\text { leted }\end{array}$ & $\begin{array}{l}\text { Comp } \\
\text { leted }\end{array}$ & $\begin{array}{l}\text { Not } \\
\text { Comp } \\
\text { leted }\end{array}$ \\
\hline KQ & $\begin{array}{l}\text { Comp } \\
\text { leted }\end{array}$ & $\begin{array}{l}\text { Not } \\
\text { Comp } \\
\text { leted }\end{array}$ & $\begin{array}{l}\text { Not } \\
\text { Comp } \\
\text { leted }\end{array}$ & $\begin{array}{l}\text { compl } \\
\text { eted }\end{array}$ & $\begin{array}{l}\text { Not } \\
\text { Comp } \\
\text { leted }\end{array}$ & $\begin{array}{l}\text { Comp } \\
\text { leted }\end{array}$ & $\begin{array}{l}\text { Not } \\
\text { Comp } \\
\text { leted }\end{array}$ \\
\hline $\mathbf{A Q}$ & $\begin{array}{l}\text { Comp } \\
\text { leted }\end{array}$ & $\begin{array}{l}\text { Not } \\
\text { Comp } \\
\text { leted }\end{array}$ & $\begin{array}{l}\text { Not } \\
\text { Comp } \\
\text { leted }\end{array}$ & $\begin{array}{l}\text { compl } \\
\text { eted }\end{array}$ & $\begin{array}{l}\text { Not } \\
\text { Comp } \\
\text { leted }\end{array}$ & $\begin{array}{l}\text { Comp } \\
\text { leted }\end{array}$ & $\begin{array}{l}\text { Not } \\
\text { Comp } \\
\text { leted }\end{array}$ \\
\hline $\mathbf{R Q}$ & $\begin{array}{l}\text { Comp } \\
\text { leted }\end{array}$ & $\begin{array}{l}\text { Not } \\
\text { Comp } \\
\text { leted }\end{array}$ & $\begin{array}{l}\text { Not } \\
\text { Comp } \\
\text { leted }\end{array}$ & $\begin{array}{l}\text { compl } \\
\text { eted }\end{array}$ & $\begin{array}{l}\text { Not } \\
\text { Comp } \\
\text { leted }\end{array}$ & $\begin{array}{l}\text { Comp } \\
\text { leted }\end{array}$ & $\begin{array}{l}\text { Not } \\
\text { Comp } \\
\text { leted }\end{array}$ \\
\hline $\begin{array}{l}\text { Feedb } \\
\text { ack } \\
\text { Form }\end{array}$ & $\begin{array}{l}\text { Comp } \\
\text { leted }\end{array}$ & $\begin{array}{l}\text { Not } \\
\text { Comp } \\
\text { leted }\end{array}$ & $\begin{array}{l}\text { Not } \\
\text { Comp } \\
\text { leted }\end{array}$ & $\begin{array}{l}\text { compl } \\
\text { eted }\end{array}$ & $\begin{array}{l}\text { Not } \\
\text { Comp } \\
\text { leted }\end{array}$ & $\begin{array}{l}\text { Comp } \\
\text { leted }\end{array}$ & $\begin{array}{l}\text { Not } \\
\text { Comp } \\
\text { leted }\end{array}$ \\
\hline
\end{tabular}




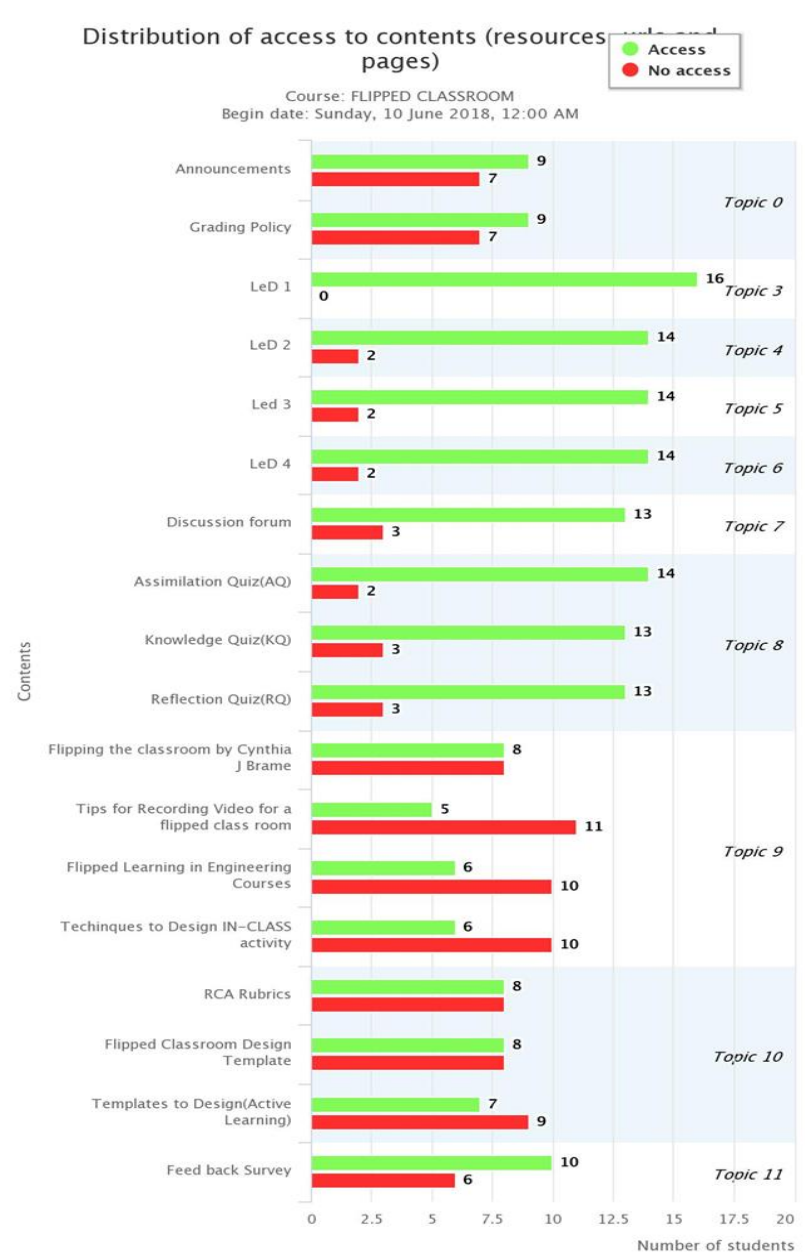

Research Findings Transition Pattern of engagement of learners across LeD, LbD, LxI, and LxT

\section{ANALYSIS OF LEARNING}

\section{Gross Learning in the Course}

Analysis of the learning of the students is done by analyzing the marks obtained by the participants in attempting various quizzes and activities. There were 3 types of quizzes and activities for the participants. The weighted marks for each of them are given below:
1. Knowledge Quiz
[10 Marks]
2. Reflection Quiz
[10 Marks]
3. Assimilation Quiz
[10 Marks]
Total
30 Marks

Table 3: number of participants who attempted each activity and the average, marks and percentage they scored.

\begin{tabular}{|l|l|l|l|l|}
\hline & KQ & RQ & AQ & All \\
\hline
\end{tabular}

\begin{tabular}{|l|c|c|c|c|}
\hline $\begin{array}{l}\text { No of } \\
\text { Persons } \\
\text { attempted }\end{array}$ & 10 & 10 & 10 & 11 \\
\hline $\begin{array}{l}\text { Average } \\
\text { Marks }\end{array}$ & 5.535 & 6.875 & 4.867 & 66.11 \\
\hline $\begin{array}{l}\text { Maximum } \\
\text { Marks }\end{array}$ & 10 & 10 & 7.33 & 100 \\
\hline $\begin{array}{l}\text { Average } \\
\text { Percentage }\end{array}$ & - & - & - & 61.53 \\
\hline
\end{tabular}

Transition Pattern of Learning across Graded Activity Quizzes

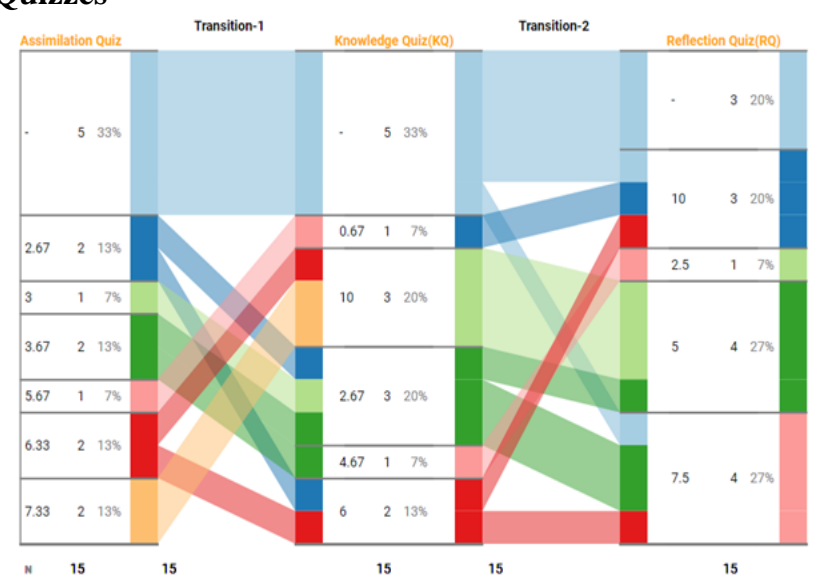

Conclusions

Perception of Learning

For each of the parameters to analyze perception of learning, we can see that the participants seem to have a good perception about the learning offered by the course

\section{Perception of Engagement}

Suggestions on the course and share your suggestions on how this course can made more useful and effective in meeting your learning needs.

\section{Analysis Of Perception}

Perception of learners about the course

We can analyze the overall perception of learners through their feedback in the three surveys

Perception of Learning

Perception of Engagement

Perception of Usability

Perception of Learning

For each of the parameters to analyze perception of learning, we can see that the participants seem to 
have a good perception about the learning offered by the course

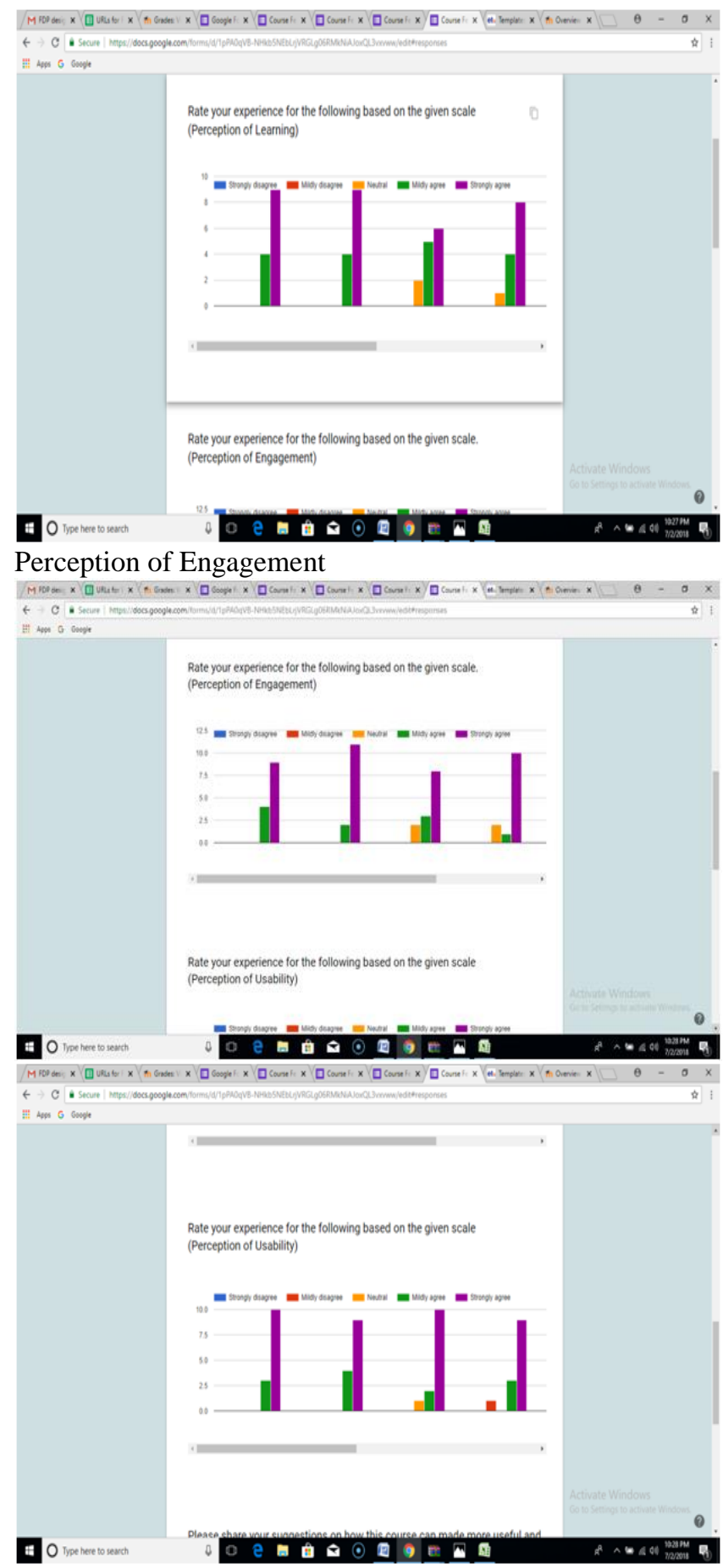

Feed back on the course

Suggestions on the course and share your suggestions on how this course can made more useful and effective in meeting your learning needs.

Responses received : 10 no.

1. Nice Experience (2)
2. It's helpful. Thank you.

3. There needs to be LbDs added post the LeDs, to gauge the understanding

4. You must include resources under LxT and as RQ is not based on Discussion forum properly because in discussion forum proper steps are not provided. In the beginning, I was confused about lbd activity under each led.

5. None

6. Good

7. Overall a good FC Design........No completion tick mark given to LeDs and LbD's, Proper instructions are not given in discussion forum,

8. The LbD also may be graded as the learner may otherwise skip watching the videos. Videos are very engaging.

9. Reflection Quiz not appropriate as I did not participate in the forum so clicked 0 as the answer which was marked in correct.

10. No suggestions

\section{Conclusions}

The cloud: a smart move for higher education, where students and faculty can interact through this platform. In this paper, we have designed flipped class room on gnomio platform . The main objective of this work is to assess the efficiency of the learning through online mode. We have analyzed the transition pattern of engagement of learners across LeD, LbD, LxI, and LxT and it is observed that the gross learning on the platform was $61.53 \%$. Transition Pattern of Learning across Graded Activity Quizzes is also done. Each of the parameters- perception of learning, Usability and engagement of the course are analyzed through feedback survey. As per the analytics, we can see that the participants seem to have a good perception about the learning offered by the course.

\section{Acknowledgement}

Authors gratefully acknowledge IIT Bombay team Prof Pathak and mentors of the FDP: Mentoring Educators in Education Technology301x from May17 2018 to July 25,2018

\section{References}

1. The Mapping of On-Line Learning to Flipped Classroom: Small Private Online Course Muqiang Zheng 1 , Chien-Chi Chu 2,*, Yenchun Jim Wu 
$3,4, *$ ID and Wanxing Gou , Received: 29 January 2018; Accepted: 5 March 2018; Published: 9 March 2018 Sustainability 2018, 10, 748; doi:10.3390/su10030748

2. Sams, A., \& Bergmann, J. (2012).Flip your classroom: Reach every student in every class every day. International Society for Technology in Education (ISTE)

3. (PDF) Flipped Classroom References. Available from:

https://www.researchgate.net/publication/2643794 48_Flipped_Classroom_References [accessed Nov 30 2018].

4. Sahin, Muhammed; Fell Kurban, Caroline (2016). The Flipped Approach to Higher Education: Designing Universities for Today's Knowledge Economies and Societies. UK: Emerald. ISBN 978-1786357441.

5. Allam, C. (2006) in Bijnens, M., Vanbuel, M., Verstegen, S., Young C., Handbook on Digital Video and Audio in Education, Creating and using audio and video material for educational purposes, The Videoaktiv Project.

6. Book on Promoting Active Learning through the Flipped Classroom Model, edited by Keengwe, Jared,IGI Global Right

7. Impact of Flipped Classroom Design on Student Performance and Perceptions in a Pharmacotherapy CourseCathy L. Koo, PharmD, Elaine L. Demps, PhD, Charlotte Farris, PharmD, 0 John D. Bowman, MS, Ladan Panahi, PharmD, and Paul Boyle, BS Am J Pharm Educ. 2016 Mar 25; 80(2): 33. 